\title{
Upgrading a District Heating System by Means of the Integration of Modular Heat Pumps, Geothermal Waters, and PVs for Resilient and Sustainable Urban Energy
}

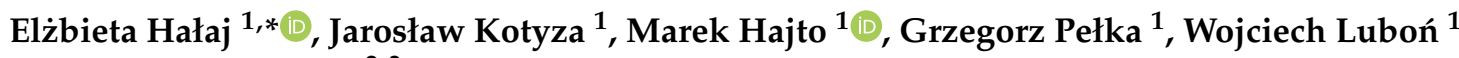 \\ and Pawel Jastrzębski ${ }^{2,3}$
}

check for

updates

Citation: Hałaj, E.; Kotyza, J.; Hajto, M.; Pełka, G.; Luboń, W.; Jastrzębski, P. Upgrading a District Heating System by Means of the Integration of Modular Heat Pumps, Geothermal Waters, and PVs for Resilient and Sustainable Urban Energy. Energies 2021, 14, 2347. https://doi.org/ 10.3390/en14092347

Academic Editor: Henk Witte

Received: 24 February 2021

Accepted: 19 April 2021

Published: 21 April 2021

Publisher's Note: MDPI stays neutral with regard to jurisdictional claims in published maps and institutional affiliations.

Copyright: (c) 2021 by the authors. Licensee MDPI, Basel, Switzerland. This article is an open access article distributed under the terms and conditions of the Creative Commons Attribution (CC BY) license (https:/ / creativecommons.org/licenses/by/ $4.0 /)$.
1 AGH University of Science and Technology, Faculty of Geology, Geophysics and Environmental Protection, 30-059 Krakow, Poland; kotyza@agh.edu.pl (J.K.); mhajto@agh.edu.pl (M.H.); pelka@agh.edu.pl (G.P.); lubon@agh.edu.pl (W.L.)

2 Faculty of Management, AGH University of Science and Technology, 30-059 Krakow, Poland; pjastrze@agh.edu.pl

3 MPEC S.A.-Krakow District Heating Company, 30-969 Krakow, Poland

* Correspondence: ehalaj@agh.edu.pl

\begin{abstract}
Krakow has an extensive district heating network, which is approximately $900 \mathrm{~km}$ long It is the second largest city in terms of the number of inhabitants in Poland, resulting in a high demand for energy - for both heating and cooling. The district heating of the city is based on coal. The paper presents the conception of using the available renewable sources to integrate them into the city's heating system, increasing the flexibility of the system and its decentralization. An innovative solution of the use of hybrid, modular heat pumps with power dependent on the needs of customers in a given location and combining them with geothermal waters and photovoltaics is presented. The potential of deep geothermal waters is based on two reservoirs built of carbonate rocks, namely Devonian and Upper Jurassic, which mainly consist of dolomite and limestone. The theoretical potential of water intake equal to the nominal heating capacity of a geothermal installation is estimated at 3.3 and 2.0 MW, respectively. Shallow geothermal energy potential varies within the city, reflecting the complex geological structure of the city. Apart from typical borehole heat exchangers (BHEs), the shallower water levels may represent a significant potential source for both heating and cooling by means of water heat pumps. For the heating network, it has been proposed to use modular heat pumps with hybrid sources, which will allow for the flexible development of the network in places previously unavailable or unprofitable. In the case of balancing production and demand, a photovoltaic installation can be an effective and sufficient source of electricity that will cover the annual electricity demand generated by the heat pump installation, when it is used for both heating and cooling. The alternating demand of facilities for heating and cooling energy, caused by changes in the seasons, suggests potential for using seasonal cold and heat storage.
\end{abstract}

Keywords: geothermal; modular heat pumps; urban energy

\section{Introduction}

An integrated approach to urban retrofit is one that recognizes the significance of environmental, economic, and social sustainability within city projects and means targeting investments to maximize environmental, economic, and social benefits. This includes urban green growth strategies, which promote ecological public services and environmentally friendly industrial production. It means also to raise education and awareness programs among the city's inhabitants to help support technology deployment and underpin innovative research and development [1]. Moreover the "smart city" concept has become a major policy direction in many countries [2]. The challenge for cities lies in creating effective governance instruments to reinforce low-carbon energy and transformation to achieve sustainable and resilient cities [3]. 
The incorporation of shallow geothermal energy could essentially contribute to longterm improvement in the energy supply systems by slowing down the growth of energy consumption, shifting the structure of energy sources used, and by remodeling communal energy infrastructure [4]. Geothermal heat is an energy source that is reliable, resilient, ecological, and sustainable. This local energy is produced from the heat within the Earth and may have several applications, such as for the heating and cooling of buildings, generating electricity, giving warm/cold water for agricultural products in greenhouses, and for balneological purposes [5].

The latest statistical data show that approximately $75 \%$ of the population of the European Union are residents of cities [6] where dense housing favors heat distribution in heating systems. According to the statistical data of the Polish Central Statistical Office [7], district heating (DH) supplies heat to ca. $40.4 \%$ of all dwellings, mainly in large cities, where it was the dominant heat carrier (58.3\%). Additionally, 31.5\% of households, i.e., $78.2 \%$ of district heating consumers, use water for domestic purposes.

Space heating and domestic hot water preparation in Poland account for as much as $81.7 \%$ of energy consumption in households, which is also a significant financial burden on households for heating and domestic hot water purposes [7].

In large Polish cities, the heating system is based mainly on coal and other fossil fuels. Unfortunately, only $66 \%$ of heat in district heating is produced from cogeneration, which is due to the low efficiency of the cogeneration support mechanisms used in the past and means that the share of heat from these units has remained unchanged for years. According to the adopted EU directives and the global trend, the use of renewable energy sources is necessary to find other, sustainable sources that will allow resilience against climate change.

The latest trend in the development of heating networks is reducing the temperature of district heating water to a level of approximately $30-70{ }^{\circ} \mathrm{C}$ [8]. This is related to the gradual incorporation of renewable energy sources, including primarily solar systems and geothermal systems or waste heat (industrial systems, waste incineration plants, combined heat and power (CHP) systems). Modern, sustainable heating networks, the so-called 4th generation district heating $(4 \mathrm{GDH})$ system networks, are those supplying heat to buildings with low energy demand with very low transmission losses, in which low-temperature heat sources are integrated with the operation of smart energy systems [9]. Important tasks of fourth generation heating networks include, among others, the better use of heat from renewable and low-temperature sources and increasing the efficiency of using CHP and large heat pumps with the use of heat and cold storage.

Heat pumps have been proposed as elements of district heating systems in the past. This includes heat pumps using, for example, the thermal energy of river water [10] or a combined heat and power solution with heat pumps for geothermal waters [11]. Heat pumps were also considered as a tool for the accumulation of renewable resources generating electricity and their integration into district heating [12]. Generally, hybrid heat pumps show better performance in a system [13]. A geothermal heat pump system is found to be resilient when subjected to the major climate pathways [14].

The goal of the research was to examine the potential of using the available renewable sources to integrate them into the city's existing heating system, increasing the flexibility of the system and its decentralization. An innovative solution is also the use of a hybrid, modular heat pump with power dependent on the needs of customers in a given location. The intention of the paper is to provide a suitable and replicable conceptual model that considers site-specific conditions and to show a case study for advancing the existing district heating system of a big city by means of the integration of available renewable sources of energy and adjusting them for customers' needs. The findings of the presented study are site specific to the presented location; however, they can also be implemented to places with similar potential due the modular and hybrid heat pump solution.

The clear obstacle for the application of several ground- and water-sourced installations is dense urban development. This is also connected with the horizontal transport 
of thermal pollution, which may occur as more and more ground- and water-sourced installations are developed. Such a situation has been described by several authors [15-17]. Therefore, a proper simulation of thermal plumes is crucial for integrated special planning in the case of dense geothermal use in cities [18]. To evaluate potential environmental impacts and manage subsurface energy resources, gathering data from working shallow geothermal systems is becoming obligatory in Europe [19]. For this reason, the collecting of data will also become essential in Poland, especially in urban areas such as Krakow, to ensure the proper use of ground- and water-sourced heat pumps and geothermal energy.

One location for the application of the scheme is the Krakow Nowa Huta Przyszłości (KNHP) initiative [20] - a planned new urban unit built in such a way as to ensure the comprehensive revitalization of the post-industrial areas of the eastern part of Krakow on a few levels: infrastructural, functional, and social. There is a plan to develop a modern area including a science and technology park, a logistics center with an economic activity zone, and a rest and recreation area with auxiliary services (Figure 1).

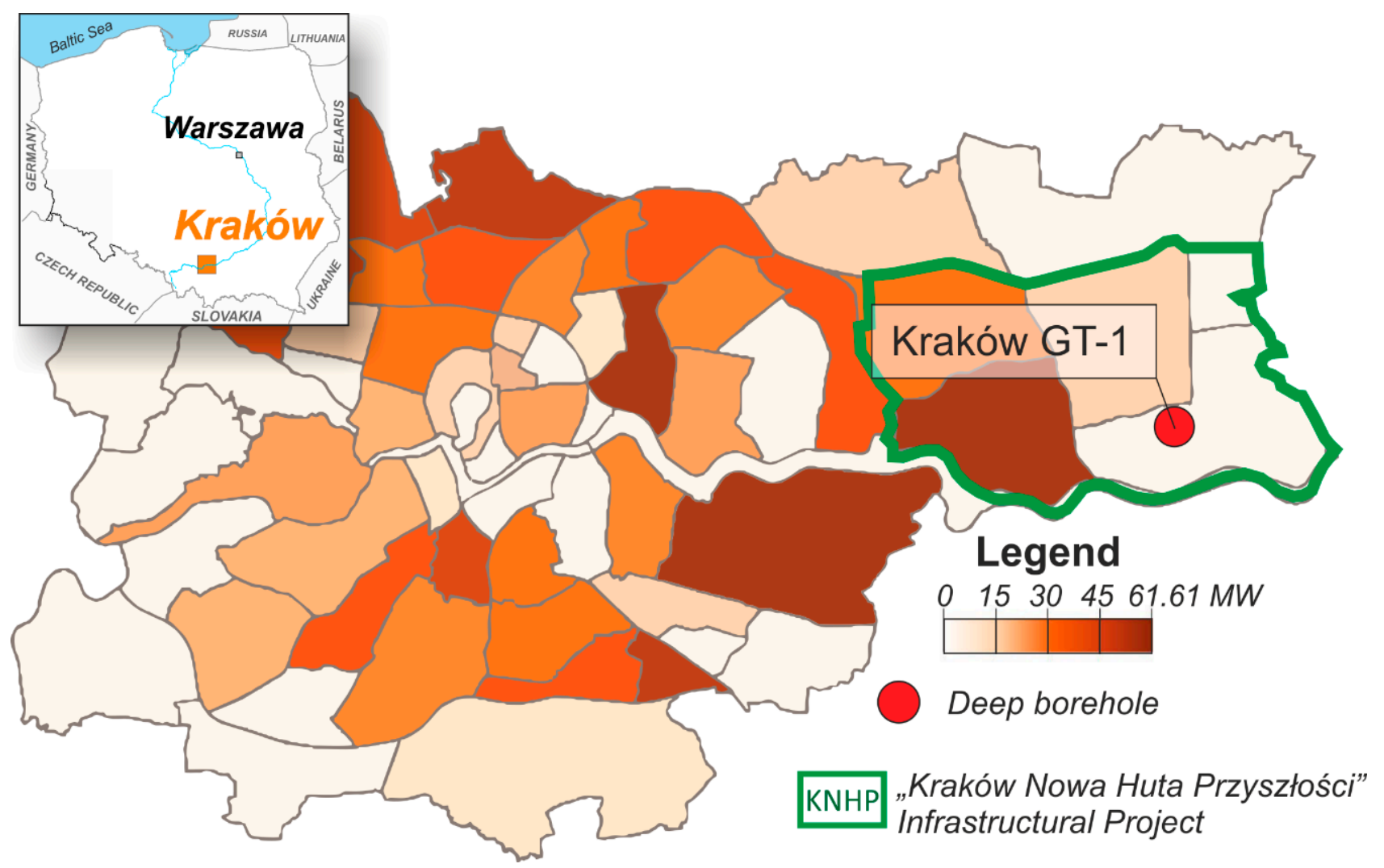

Figure 1. Expected future demand for thermal power in development areas based on the "Study of the Conditions and Directions of Spatial Development for Krakow" (adapted with permission from ref. [21] Copyright 2021 MPEC S.A., modified by M. Hajto).

\section{Materials and Methods}

To understand the heating system of Krakow and the needs of heat consumers, the documentation of the district heating operator-MPEC S.A.-was reviewed.

The most illustrative were data on the range of the heating network lines, indicating which areas in the near future were to be excluded from the operation of such a system. Based on the city's cadastral data, the main heat consumers and the potential for thermal modernization, understood in this case as the possibility of lowering the heating temperature in the buildings' rooms, were estimated.

In order to estimate the potential for shallow geothermal energy in the city, the available data on the thermal conductivity of rocks and soil in the city were analyzed. The 
location of vertical or even horizontal heat exchangers is quite common in urban areas; however, the limitations in their installation resulting from, for example, hydrogeological conditions, should also be taken into account. The hydrogeological conditions, which are also important in terms of the energetic use of groundwater, were examined.

The knowledge about deep geothermal potential has been gathered from several exploration oil wells that were drilled in the late 1960s and located in the area of our research. The results of different regional studies and resulting publications show that the eastern part of Krakow is one of the promising areas for deep geothermal exploration [22-25]. Despite this, geothermal water has not been exploited yet in the city.

In order to define the geothermal potential in Krakow, definitions of theoretical and technical potential were introduced.

The theoretical potential is an existing potential but currently impossible to be fully obtained at a given stage of technology development. It is assumed here that $100 \%$ of the existing energy resources will be used regardless of the technical and economic conditions. It only informs about potential energy resources. The theoretical potential is estimated for a single intake on the basis of the average temperature and outflow of thermal waters occurring within a given reservoir ( $\mathrm{T}_{\mathrm{W}}$ in the reservoir), assuming that they are cooled to the temperature $\mathrm{T}_{\mathrm{z}}=0{ }^{\circ} \mathrm{C}$ and full thermal power is used all year round $(\mathrm{CF}=1)$.

The technical potential is a potential for practical use at the present stage of technical development, with existing energy technologies. It is estimated on the basis of the average temperature and efficiency of thermal waters occurring within a given reservoir when the waters are cooled to the temperature $\mathrm{T}_{\mathrm{z}}=5^{\circ} \mathrm{C}$ in heat pump systems, with the value of the annual thermal power utilization coefficient of $\mathrm{CF}=0.5$. For the calculation of the technical potential, the temperature at the outflow is assumed as $\mathrm{T}_{\mathrm{w}}$.

The potential can be expressed by simplified formulas:

Well thermal capacity:

$$
\mathrm{P}_{\mathrm{t}}=0.0012 \times \mathrm{Q} \times\left(\mathrm{T}_{\mathrm{w}}-\mathrm{T}_{\mathrm{z}}\right)(\mathrm{MW})
$$

Thermal energy that can be produced during the year, taking into account the annual capacity factor, CF:

$$
\mathrm{W}_{\mathrm{t}}=\mathrm{CF} \times \mathrm{P}_{\mathrm{t}} \times 8760(\mathrm{MWh})=\mathrm{CF} \times \mathrm{P}_{\mathrm{t}} \times 8760 \times 0.0036=\mathrm{CF} \times \mathrm{P}_{\mathrm{t}} \times 31.54(\mathrm{TJ} / \text { year })
$$

where:

- $\mathrm{P}_{\mathrm{t}}$-thermal capacity of the well (MW);

- $\mathrm{W}_{\mathrm{t}}$-thermal energy from the intake (TJ/year);

- $\mathrm{T}_{\mathrm{w}}$-temperature of thermal waters (in the reservoir for theoretical potential and on the outflow for technical potential) $\left({ }^{\circ} \mathrm{C}\right)$;

- $\mathrm{T}_{\mathrm{z}}$-discharge water temperature (after heat extraction) $\left({ }^{\circ} \mathrm{C}\right)$;

- $\mathrm{Q}$-geothermal water intake capacity (estimated capacity) $\left(\mathrm{m}^{3} / \mathrm{h}\right)$;

- 8760-number of hours in a year (h/year);

- $\quad 0.0036-\mathrm{MWh}$ to TJ converter;

- 0.0012 - unit converter with the density and specific heat capacity of water;

- $\quad \mathrm{CF}$-capacity factor of the geothermal installation in a year $(\mathrm{CF}=1$-year-round use; $\mathrm{CF}=0.5$-intake works 6 months a year).

\subsection{Expected Capacity of Intakes of Target Reservoirs in the Area of Planned Works}

In order to estimate the expected efficiency of the intakes, assumptions were made regarding the basic hydrogeological parameters of thermal water reservoirs and the intake parameters, which are presented in Table 1. 
Table 1. Predicted parameters of geothermal water intakes in the south-eastern part of Krakow (adapted with permission from ref. [23] Copyright 2021 J. Kotyza, modified by M. Hajto).

\begin{tabular}{|c|c|c|}
\hline Parameter & Upper Jurassic Reservoir $\left(\mathrm{J}_{3}\right)$ & Devonian Reservoir (D) \\
\hline Reservoir type & fissure-karst reservoir & fissure-karst reservoir \\
\hline Well end depth $(\mathrm{m})$ & \multicolumn{2}{|c|}{$1820( \pm 10 \%)$} \\
\hline Aquifer interval depth, H (top/base) (m b.g.l.) & $\begin{array}{l}540 \\
690\end{array}$ & $\begin{array}{l}1500 \\
1800\end{array}$ \\
\hline Depth of the static water table (m b.g.l.) & $\begin{array}{c}20 \\
\text { sub-artesian }\end{array}$ & $\begin{array}{c}180 \\
\text { sub-artesian }\end{array}$ \\
\hline Hydraulic conductivity (m/s) & $4 \times 10^{-6}$ & $3 \times 10^{-6}$ \\
\hline Reservoir water mineralization, $\mathrm{M}\left(\mathrm{kg} / \mathrm{m}^{3}\right)$ & 10 & 100 \\
\hline Total thickness of stratigraphic units, m (m) & 230 & 1100 \\
\hline Total thickness of aquifers, $\mathrm{m}_{\mathrm{p}}(\mathrm{m})$ & 150 & 40 \\
\hline Temperature in reservoir/outlet $\left({ }^{\circ} \mathrm{C}\right)$ & $25 / 24$ & $53 / 50$ \\
\hline Screen length, L (m) & 150 & 30 \\
\hline Outer diameter of the screen, $\varphi$ (inch) & $65 / 8$ & $65 / 8$ \\
\hline Exploiting depression of the well, S (m) & 40 & 15 \\
\hline Cone of depression radius $(\mathrm{m})$ & 240 & 75 \\
\hline Exploitation capacity of the well, $\mathrm{Q}_{\mathrm{z}}{ }^{*}, \mathrm{Q}_{\mathrm{n}}{ }^{* *}\left(\mathrm{~m}^{3} / \mathrm{h}\right)$ & 70 * & $55^{* *}$ \\
\hline
\end{tabular}

To estimate the efficiency of water intakes, the formulas of classical hydrogeology used in the basics of calculating groundwater filtration for the inflow to a single complete and incomplete well under the stable filtration conditions were used [26,27]. In the calculations, the Dupuit scheme was used, which assumes the existence of a deep, small-diameter well, working with efficiency and depression unchanged in time. The aquifer has unlimited distribution, a constant thickness, and a constant value of the filtration coefficient. Before pumping the wells, the water table is horizontal, and the available aquifers are confined [27]. The laminar movement of groundwater toward the borehole can be treated as plane-radial. Yields were calculated using the Dupuit-Thiem formula. Forchheimer's correction was taken into account when calculating the intake capacity (incomplete well). The assumptions adopted for the calculations, together with the results of the estimated intake capacity estimates for the Upper Jurassic and Devonian reservoirs in the planned Krakow GT-1 borehole are presented in Table 1.

The analysis of the theoretical geothermal potential allowed to start researching the use of heat pumps. The use of heat pumps in combination with a heating system causes a number of problems that should be taken into account at the investment planning stage. A modular heat pump solution using hybrid sources has been proposed, which will allow for any adaptation of the modules used in the heating system. The benefits of the modular combination of heat pumps have been analyzed. An innovative solution was proposed for the use of heat pumps in a modular manner, connecting them depending on the needs and possibilities of the network. Possible locations for the use of such heat sources in the city were also proposed. Modular heat pumps can consist of smaller units; however, for cooperation with the heating system, high-power heat pumps are also dedicated for use and can be plugged into the system. The effect of using heat pumps causes an increase in the demand for electricity. The idea of supporting heat pumps with electricity from photovoltaic panels was estimated on the basis of available cadastral data on the availability of suitable roofs and considerations for the possibility of balancing the thermal power of heat pumps with electricity from photovoltaic panels during the day. A system based on the self-consumption of such energy is the most effective, with the help of heat pumps. 
Obstacles that reduce the potential of installing such sources or even prevent installation have also been indicated.

\subsection{Krakow, Poland-A Case Study}

Krakow is situated on the Vistula River in the Małopolskie Voivodeship, south of Poland. Its area is $327 \mathrm{~km}^{2}$, with lengths of $18 \mathrm{~km}$ from south to north and $31 \mathrm{~km}$ from west to east. Krakow is the second largest city in terms of the number of inhabitants in Poland, which results in a high demand for energy-for both heating and cooling. The 2018/2019 heating season lasted for 236 days (5664 h)-starting on September 26 and ending on May 20. The total demand for heat in Krakow can be estimated at approximately $15,000 \mathrm{TJ} / \mathrm{y}[28]$.

The power industry of the city of Krakow is based on coal; this applies to both industrial power engineering and small heat producers producing heat for their own needs. The 2018 report of the Energy Regulatory Office indicates that 90.1\% of heat used in the Małopolskie Voivodeship comes from coal [29]. This is above the national average and is a significant challenge in terms of the improvement of air pollution by the successive elimination of low-emission sources of these pollutants in Krakow.

Krakow has an extensive district heating network. In 2018, it was $879.6 \mathrm{~km}$ long [30]. However, this network still does not reach all residents, including a number of buildings and tenement houses located in the city center. A total of 30 new potential development areas for the district heating network have been defined for the city with a total target power demand of 610.3 MW. The development areas are mainly located in the city center. As part of the development of the heat market, the decommissioning of boiler houses and coal-fired stoves is planned to connect new customers, with a total estimated power demand of 211.2 MW by 2024. The heat suppliers to the municipal heating system are 3 large energy companies, 50 ecological gas-fired boiler houses, and 1 oil-fired boiler house with an installed capacity of $29.5 \mathrm{MW}$ [30]. All entities provide heat, the medium of which is hot water.

The demand for heat power from the district heating network in the area of the Municipality of Krakow in winter is at the level of 1552 MW, while in summer it is at the level of 147.6 MW. In recent years, the demand for thermal power has been increasing both during the heating and summer periods. Total sales of thermal capacity in 2018 amounted to $1807 \mathrm{MW}$ (Table 2).

Table 2. Basic parameters of the heat market in Krakow (compiled on the basis of [30], adapted with permission from ref.

[30]. Copyright 2021 MPEC S.A.).

\begin{tabular}{ccccc}
\hline $\begin{array}{c}\text { Total Heat Demand } \\
\text { in Krakow }\end{array}$ & $\begin{array}{c}\text { Share of District } \\
\text { Heat in the Heat } \\
\text { Market }\end{array}$ & $\begin{array}{c}\text { Sales of } \\
\text { District Heat }\end{array}$ & $\begin{array}{c}\text { Residential Sector } \\
\text { Customers }\end{array}$ & $\begin{array}{c}\text { Demand for Heat from the } \\
\text { Residential Sector in Krakow }\end{array}$ \\
\hline $\mathrm{TJ} / \mathrm{y}$ & $\%$ & $\mathrm{TJ} / \mathrm{y}$ & $\%$ & $\begin{array}{c}\text { Completed by } \\
\text { MPEC S.A. }\end{array}$ \\
\hline $15,000 *(\mathrm{ok} .2 .5 \mathrm{TWh} / \mathrm{y})$ & $65 \%$ & 9473 & 60.8 & $\mathrm{TJ} / \mathrm{y}$ \\
\hline
\end{tabular}

The structure of heat consumers, taking into account the ordered thermal capacity in 2018, is presented in Figure 2. The largest share in the structure of MPEC S.A. recipients in Krakow is taken by the residential sector, which in total requires approximately $61 \%$ of thermal power. This sector includes housing communities and municipal buildings, housing cooperatives, and individual recipients. Business entities ordered $24 \%$ of heat, while education and healthcare ordered $12 \%$ and $3 \%$, respectively. The most important factor determining the increase in heat sales by MPEC S.A. is the development of residential buildings in the area of the company's operations and legal regulations forcing the replacement of coal furnaces with ecological heating. 


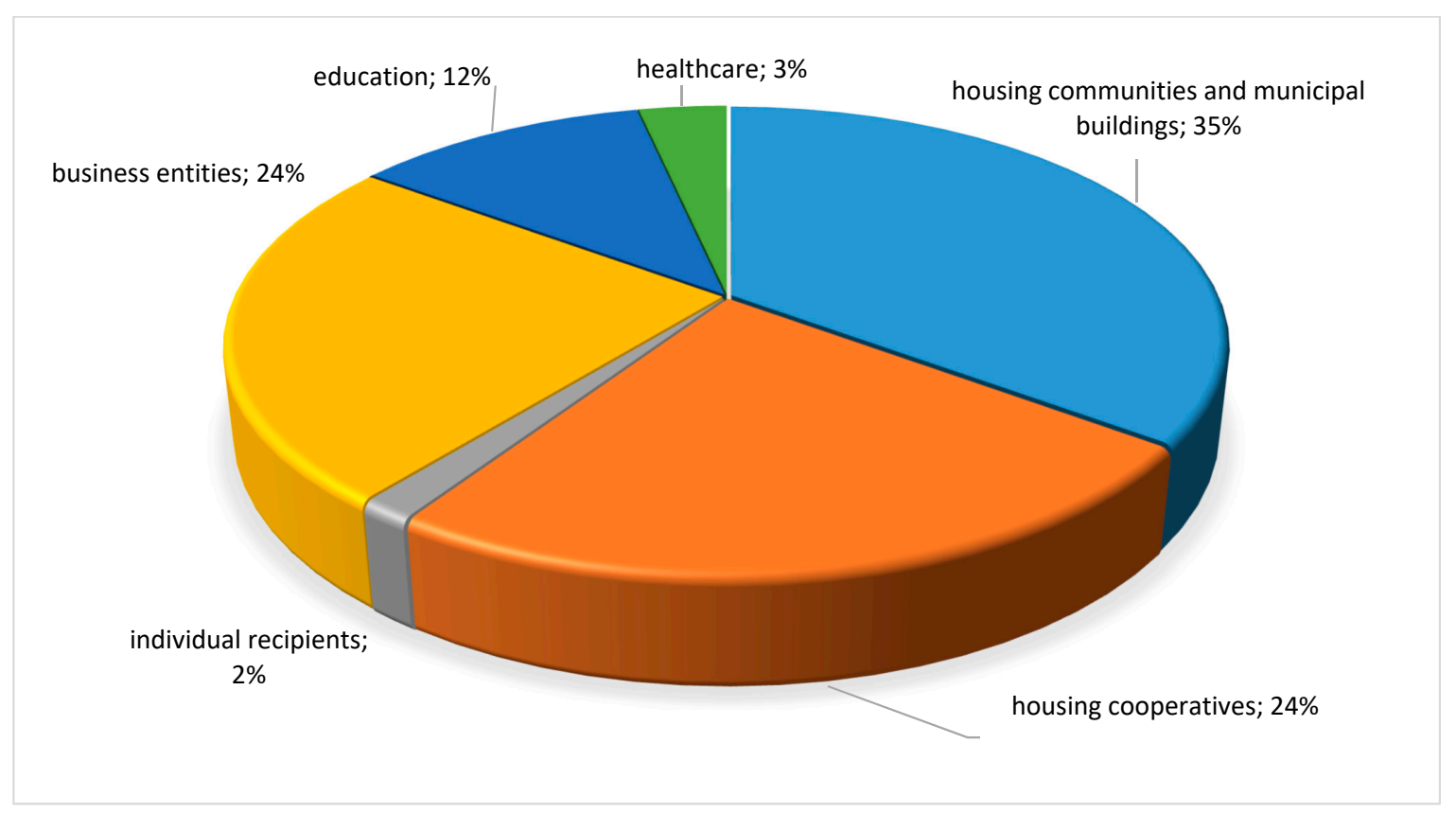

Figure 2. The structure of heat consumers in Krakow, taking into account the ordered thermal capacity in 2018 (adapted with permission from ref. [30]. Copyright 2021 MPEC S.A.).

Despite the extensive heating network and new investment plans of MPEC S.A., mainly due to the lack of economic justification, the development of the heating network toward peripheral housing estates has not been considered. The lack of a heating network in some locations may be inconvenient to residents but creates opportunities for the development of geothermal heat pumps, geothermal or photovoltaic solutions, and their integration in the district heating network. Moreover, the incorporation of geothermal or heat pump units may decrease the number of overloaded district heating nodes. On the other hand, buildings' demand for usable energy is high and significantly differs from the currently applicable standards. If it is necessary to lower the temperature on the supply side, it is necessary to carry out modernization works in the buildings. Figure 3 shows the usable energy demand of several buildings.

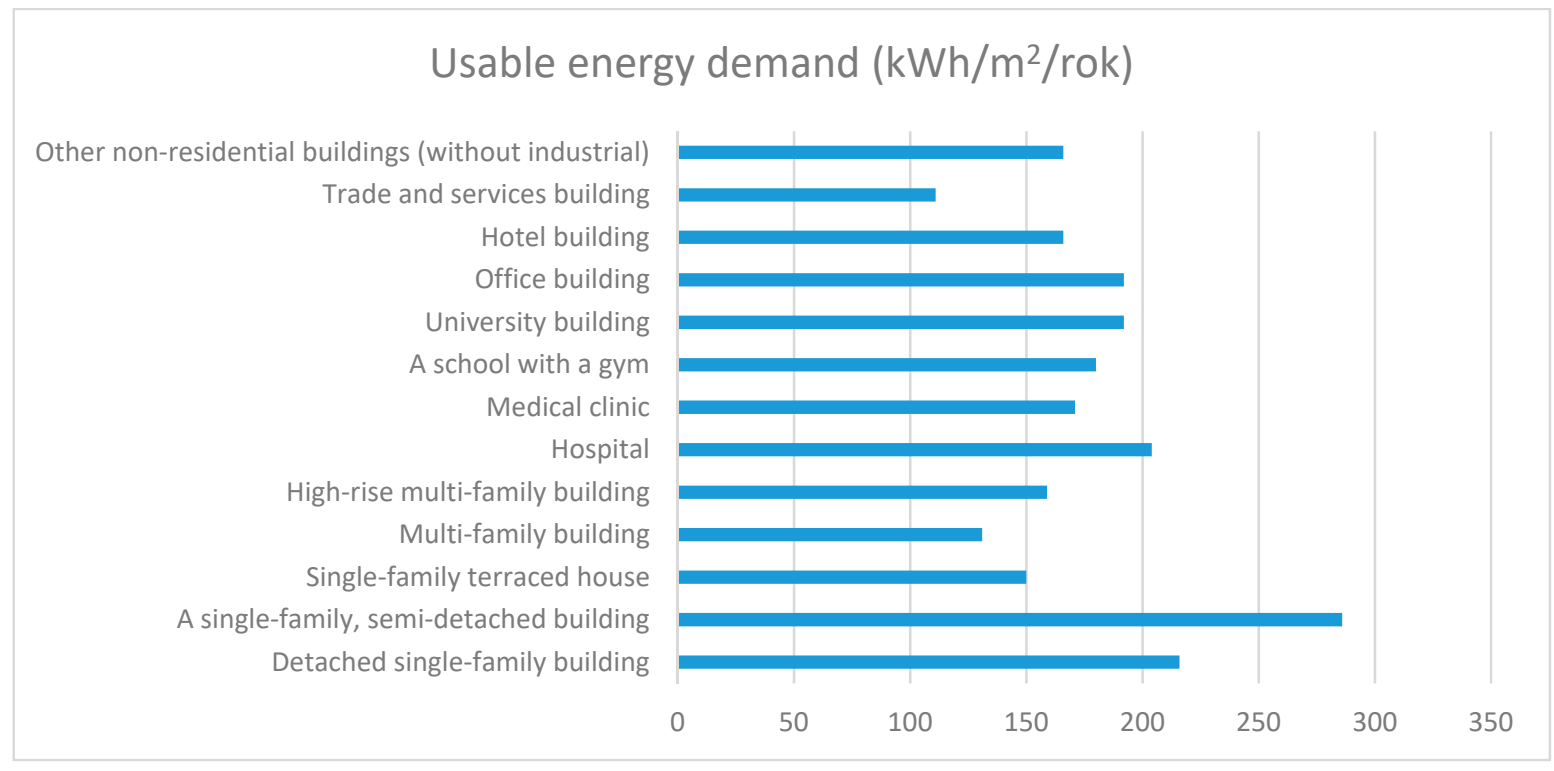

Figure 3. Usable energy demand in Poland according to type of building (source: [31]). 
High-capacity heat pumps are systematically gaining importance in the heating industry market. They are used in every climatic zone and fulfill a wide range of functions. With an appropriate system design, you can use both heating and cooling opportunities, transforming one-way energy consumption into cyclical energy management. Heat plants and heat and power plants are expected to have very high prospects for the use of heat pumps. Table 3 presents positive examples of the various applications of high-capacity heat pumps. High-power heat pumps were considered for use in Krakow in cooperation with geothermal sources and the district heating network.

Table 3. Examples of various applications of high-capacity heat pumps in Europe.

\begin{tabular}{|c|c|c|c|c|c|c|}
\hline Factor/Item & $\begin{array}{c}\text { District } \\
\text { Heating } \\
\text { Network in } \\
\text { Dramen }\end{array}$ & $\begin{array}{c}\text { District } \\
\text { Heating } \\
\text { Network in } \\
\text { Vienna }\end{array}$ & $\begin{array}{c}\text { Military } \\
\text { Hospital in } \\
\text { Budapest }\end{array}$ & $\begin{array}{l}\text { District } \\
\text { Heating } \\
\text { System in } \\
\text { Bergheim }\end{array}$ & $\begin{array}{l}\text { District } \\
\text { Heating in } \\
\text { Mänttä- } \\
\text { Vilppula }\end{array}$ & $\begin{array}{l}\text { The Pope John } \\
\text { Paul II Center }\end{array}$ \\
\hline Country & Norway & Austria & Hungary & Germany & Finland & Poland \\
\hline $\begin{array}{l}\text { Heating } \\
\text { capacity }\end{array}$ & 13.2 MW & $255 \mathrm{~kW}$ & $3800 \mathrm{~kW}$ & $2 \times 293 \mathrm{~kW}$ & 158 & $1.3 \mathrm{MW}$ \\
\hline $\begin{array}{l}\text { Cooling } \\
\text { capacity }\end{array}$ & n.a. & n.a. & $2980 \mathrm{~kW}$ & n.a. & n.a. & 1.1 MW \\
\hline $\mathrm{COP}$ & 3.05 & 5.3 & 7.23 & 4.4 & 2.0 & 3.6 \\
\hline EES & n.a. & n.a. & 5.41 & n.a. & n.a. & n.a. \\
\hline Refrigerant & R717 & ÖKO1 & R134a & R134a & ÖKO1 & R407c \\
\hline Heating source & water & water & water & water & water & ground \\
\hline $\begin{array}{c}\text { Supplied } \\
\text { temperature }\end{array}$ & $90^{\circ} \mathrm{C}$ & $70-85^{\circ} \mathrm{C}$ & $33^{\circ} \mathrm{C}$ & $\max .73^{\circ} \mathrm{C}$ & $70-120^{\circ} \mathrm{C}$ & $40-50^{\circ} \mathrm{C}$ \\
\hline Source of data & [32] & [32] & [33] & [32] & [32] & [34] \\
\hline
\end{tabular}

The main obstacles limiting the use of heat pumps in industry are:

- Extreme requirements for the return on investment are assumed. This is further complicated by the relatively low price of fossil energy;

- Risk aversion, in particular in relation to heat pumps, which are not always trusted and are seen as new, untested technology;

- Limited availability or lack of examples of best practice that could inspire confidence in new solutions;

- Designing technological solutions by taking into account (though not always justified) the high temperatures of heat carriers;

- Structural barriers in the industry;

- High transaction costs of process conversion because many existing processes are based on steam;

- The need to integrate competences and responsibilities in order to use these systems in the future for the energy optimization of industrial processes and commercial applications.

Despite the above limitations, the use of heat pumps integrated with the city's district heating system offers wide opportunities to reduce $\mathrm{CO}_{2}$ and increase the efficiency of the system.

\section{Results and Discussion}

\subsection{Shallow and Deep Geothermal Potential in Krakow}

Shallow geothermal resources differ within the city. This is connected both with ground and water potential. According to the results obtained during the implementation of the GeoPLASMA-CE project [35], as well as further studies [36], the thermal conductivity of the soil in the geological profile in Krakow up to $100 \mathrm{~m}$ b.g.l. differs from 1.65 to 
$3.4 \mathrm{~W} / \mathrm{m} / \mathrm{K}$. This means that the specific heat extraction rate will range from ca. 38 to $54 \mathrm{~W} / \mathrm{m}$. The areas with the most favorable conditions for the use of ground heat pumps are found in the southern and western part of Krakow, mostly in areas where there is no district heating network or where buildings are supplied by heating chambers serving many customers.

Estimations made within the GeoPLASMA-CE [35] project show that in the area of Krakow a considerable shallow geothermal potential occurs, both in rocks and in groundwater [36]. The evaluated inventory exposed that about 200 small and 24 bigger geothermal heat pump installations with a total capacity of approximately $5 \mathrm{MWt}$ were working in Krakow at the end of 2018, apart from heat pumps with a horizontal heat exchanger and air heat pumps [37]. The total length of the borehole heat exchangers (BHEs) of these systems was assessed to be about $92 \mathrm{~km}$ [37]. An optimistic scenario of shallow geothermal heat growth [38] reflecting the city's heat demand in 2050 assumes that geothermal heat pumps could be responsible for about $1.2 \%$ of this demand (as, in $2018 / 2019$, the share of heat pumps in the total balance of heat production in the city was less than $0.3 \%[39])$.

The city area is located partially in the area of the Major Groundwater Reservoirs, which are strategic groundwater resources to supply the people and the basic sectors of the economy that require high-quality water. The Major Groundwater Reservoirs must have a potential capacity above $70 \mathrm{~m}^{3} / \mathrm{h}$, an intake capacity above $417 \mathrm{~m}^{3} / \mathrm{h}$, and a hydraulic transmissivity above $10 \mathrm{~m}^{2} / \mathrm{h}$, which also makes them very valuable for energetic purposes. However, rigorous standards should be preserved. Moreover, water-sourced heat pumps (WSHPs) can be a good source for both heating and cooling, which is highly desirable in urban areas.

The key aspect of the efficient use of thermal water resources is the existence of appropriate geological conditions determining the distribution of basic hydrogeological and geothermal parameters of the formations that build geothermal reservoirs. The results of the research carried out so far indicate a moderate energy potential of deep groundwater reservoirs (below $500 \mathrm{~m}$ below sea level) in the Krakow region. The in-depth lithological and stratigraphic characteristics indicate that potential geothermal water reservoirs in the north-eastern part of the city may be associated with the Upper Jurassic carbonate formations (J3) and the Middle and Upper Devonian (D2 + D3).

The relatively well-known deep geological profile is accompanied by a rather poor hydrogeological survey, resulting from the specificity of oil exploration. Estimates of the efficiency of thermal water intakes in the Upper Jurassic and Devonian reservoirs, assuming optimal water-bearing horizon availability parameters, indicate the possibility of obtaining a capacity of 43 to approximately $52 \mathrm{~m}^{3} / \mathrm{h}$ of thermal waters with temperatures from 27 to $51^{\circ} \mathrm{C}$ at the well head (Table 1). In order to obtain thermal waters, it is proposed to drill one or two geothermal boreholes and to make the reservoir level of the Upper Jurassic or Devonian (D2 + D3) available.

Geothermal waters in the area are of sodium chloride ( $\mathrm{Na}-\mathrm{Cl})$ brines [23]. The water mineralization, temperature, and content of specific therapeutic components, including the presence of iodides in amounts exceeding the lower threshold of therapeutic effect, indicate that these waters are prospective for therapeutic and recreational purposes. The concentrations of other components of balneotherapeutic significance were not determined in the conducted chemical analyses, but their presence cannot be excluded. Therefore, geothermal bathing and/or healing facilities as a supplement to energetic purposes can be proposed.

\subsection{The Concept of Using Deep Geothermal Waters}

The north-eastern area considered for geothermal application is an area with a low degree of urbanization. There are no centralized heat sources in this area and no district heating. The buildings are heated with traditional stoves or individual boiler rooms. Due to the expected balneotherapeutic properties of geothermal waters, and at the same time 
due to the lack of an appropriate concentration of heating needs in this area, it is planned to use the water and the heat it contains for the needs of the facilities of the newly established Balneological and Recreation Center. The construction of the center is favored by its planned location on the outskirts of Krakow.

The main factors determining the method of exploitation and the scope of thermal water management are the operating parameters of the intake, taking into account the efficiency and the general mineralization of thermal waters. The parameters are a derivative of the deposit parameters of individual thermal water reservoirs, usually their depth. The above parameters overlap with economic factors as well as technical and environmental conditions related to the possible disposal of used water. Taking into account the above factors, three variants of the exploitation of thermal waters in the area were proposed, namely:

\subsubsection{Option 1-Devonian (1800 m b.g.l. Borehole)}

The first borehole, with a target depth of $1800 \mathrm{~m}$, which is assumed to be a production well, will be used to investigate the hydrogeothermal conditions of the Upper Jurassic reservoir and the Middle and Upper Devonian (D2 + D3). In the case of obtaining favorable yields and temperatures in the provided Devonian aquifers, i.e., not worse than the estimated ones, it may be the target, operational reservoir. Due to the expected high mineralization of groundwater, the groundwater will have to be injected (after use) into the aquifer with an injection well of a similar final depth.

\subsubsection{Option 2-Upper Jurassic ( $1800 \mathrm{~m}$ b.g.1. Borehole)}

An alternative aquifer is the Upper Jurassic reservoir (J3). This aquifer may be made available through the same well (with a target depth of $1800 \mathrm{~m}$ ), in the absence of confirmation of the favorable parameters of groundwater from the Devonian aquifers. Exploitation of the deep waters of the Upper Jurassic, due to their low expected mineralization, will not require their reinjection, which eliminates the need to drill a second (injection) borehole. The used geothermal water, after possible mixing with fresh water, will be discharged into surface watercourses.

\subsubsection{Option 3-Upper Jurassic ( $800 \mathrm{~m}$ b.g.l. Borehole)}

The Upper Jurassic geothermal reservoir can be accessed through a shallower borehole, with a target depth interval of 540-690 m, intended for exploitation by only this aquifer. In this case, the recognition of the deeper, Devonian aquifer's hydrogeothermal conditions would be abandoned. As in Option 2, the exploitation of underground waters, due to the low expected mineralization, would not require their reinjection. The geothermal water used would be discharged into surface watercourses.

In accordance with the given definitions of theoretical and technical potential, for the predicted thermal water intakes of the Upper Jurassic and the Devonian, the corresponding amounts of thermal power and thermal energy production were estimated on an annual basis. For the calculations, the results of estimating the efficiency of intakes and the temperature of the outflow waters were used, which result from the assumptions regarding the method of capturing aquifers in the planned Krakow GT-1 borehole.

The energy balance of the geothermal installation in the area (Options 1, 2, and 3) is presented in Table 4. The analysis of the expected efficiency of thermal water intakes for the adopted assumptions, with the use of optimal operating conditions, indicate that one should expect a capacity of about $70 \mathrm{~m}^{3} / \mathrm{h}$ from the Upper Jurassic reservoir and about $55 \mathrm{~m}^{3} / \mathrm{h}$ from the Devonian reservoir. It should be emphasized here that the results of the calculations are strictly dependent on the adopted parameters of the well operation; apart from the adopted values of the filtration coefficient, the following have a significant influence: the interval and the diameter of the well screen in the aquifer and the assumed values of exploitational depression. The obtained results of the calculations are within the limits of the parameters given by various authors cited in this project of geological works. 
Table 4. Predicted heat potential of thermal waters of the Krakow GT-1 well.

\begin{tabular}{lcc}
\hline \multicolumn{1}{c}{ Parameter } & Upper Jurassic Reservoir (J3) & Devonian Reservoir (D) \\
\hline Well capacity, $\mathrm{Q}\left(\mathrm{m}^{3} / \mathrm{h}\right)$ & 70 & 55 \\
\hline Temperature in reservoir/ outlet $\left({ }^{\circ} \mathrm{C}\right)$ & $25 / 24$ & $53 / 50$ \\
\hline Theoretical potential: & & $3.3 \mathrm{MW}$ \\
- nominal power of the well & $2.0 \mathrm{MW}$ & $105.3(29,244.8)$ \\
\hline thermal energy production $(\mathrm{TJ} /$ rok) $(\mathrm{MWh} / \mathrm{rok})$ & $63.2(17,556.9)$ & $2.8 \mathrm{MW}$ \\
\hline Technical potential $(\mathrm{CF}=0.5$; water temperature at the outlet): & $1.5 \mathrm{MW}$ & $44.7(12,415.3)$ \\
\hline - nominal power of the well & $24.0(6671.6)$ & \\
\hline
\end{tabular}

The new installations are in a region where a special zone of economic activity, Krakow Nowa Huta Przyszłości, is currently being created. As this project assumes a wide use of the available space for entities from various industries, the presence of geothermal waters in this area opens up new opportunities and fits perfectly into the assumptions of the project. Due to the expected parameters of geothermal waters, it is suggested to use the heat they contain for the energy needs of local heat plants. According to the Krakow Nowa Huta Przyszłości project, the construction of the Balneotherapy and Recreation Center with a heat demand of $2.9 \mathrm{MW}$ is planned. Therefore, it is possible to partially cover the energy needs of this center with the use of geothermal energy. Assuming the construction of a geothermal installation with a capacity of approximately 1.5 MW (Option 1) and the use of an additional energy source, e.g., by means of heat pumps, it is possible to meet the energy demand of this center in an environmentally friendly manner.

\subsection{The Concept of Using Hybrid Modular Heat Pumps}

For the use of heat pumps in the district heating network, two innovative concepts are considered: modularity and the incorporation of high-capacity heat pumps. The concept of modular heat pumps was created for the needs of MPEC S.A. Krakow in the Center for Sustainable Development and Energy Conservation of AGH FGG\&EP in Miekinia, where new heat pumps are designed and tested [40].

In order to achieve the highest possible values of the heating capacity, low-enthalpy thermal water may be a more attractive medium than the ground for heat pump installations. An additional advantage of using water as a low-temperature energy carrier are favorable heat exchange conditions that significantly reduce the dimensions of heat exchangers. Groundwater is characterized by its fairly high and stable temperature. The most important element of the installation for the use of low-enthalpy thermal waters for heating purposes is the borehole providing the aquifer horizon. This is also the most expensive element. The advantage of water-to-water heat pumps is their especially high efficiency (COP even above 5).

Heat pump technology in a city, where a centralized district heating network is dominant, is particularly useful in places where there is no access to the heating network and its expansion is economically unjustified and in places where the existing heating infrastructure does not allow for the connection of new power (e.g., in intensively developing parts of the city). Moreover, it is useful for customers who need both heating and cooling.

There are areas in the city that, for various reasons (technical, financial, legal, etc.), cannot be subjected to district heating. Such areas include the outskirts of Krakow. Despite the lack of a heating network, the city's district heating facility may become a heat supplier to remote housing estates, and it may also use heat from renewable energy sources. For this purpose, it is necessary to develop independent, well-known heating technology based on heat pumps so that it is flexible in terms of scalability (powers from several dozen to several hundred $\mathrm{kW}$ ) and potentially usable heat sources (water, ground, air, network water, etc.). 
3.4. The Flexibility of a System Based on Renewable Distributed Sources Can Be Ensured by Using the Following Heat Pump Installations

\subsubsection{A. Brine-to-Water Heat Pump}

This heat pump type can be used in facilities that have an area for the location of the ground heat source in the form of borehole heat exchangers. A heat pump of the heating capacity of $40 \mathrm{~kW}$ requires at least 0.12 ha of area for borehole heat exchangers. However, this area may be used as a green area, parking, etc.). The brine-water heat pump is characterized by the stability of the heating power and the COP, resulting from the temperature stability of the fluid circulating in the lower source with slight seasonal fluctuations. The ground source of the heat pump can be used as a source of passive cooling. The supply temperature may be up to $55^{\circ} \mathrm{C}$. Heat pumps with R410A refrigerant and an enhanced vapor injection (EVI) cycle could be used, e.g., Galmet 42GT with a maximal water temperature between 65 and $60^{\circ} \mathrm{C}$ (for a brine temperature below $0{ }^{\circ} \mathrm{C}$ ) [41].

\subsubsection{B. Air-to-Water Heat Pump}

This is a device that may be considered useful in facilities where there is no space for the use of ground source heat pumps or where air source heat pump technology is economically justified. Air source heat pumps can be located on the ground next to the heated object. They can be also located on roofs. The heat pump can work in a reversible system, where in winter it can provide central heating $(\mathrm{CH})$ and hot domestic water (HDW) and in summer it can provide HDW and cooling). The supply temperature may be up to $55^{\circ} \mathrm{C}$. While the air source is outside air, it may cause limitations in capacity and the maximal water temperature. Regarding capacity, it could decrease from an air temperature of $7{ }^{\circ} \mathrm{C}$ to -20 . It is necessary to use an additional heat source, e.g., electric heater/boiler. In the case of maximal outlet temperature, it is possible (e.g., heat pumps with R410A refrigerant and EVI cycle or heat pumps with R290 refrigerant) to obtain $60{ }^{\circ} \mathrm{C}$ up to $-10^{\circ} \mathrm{C}$ and $50^{\circ} \mathrm{C}$ up to $-20^{\circ} \mathrm{C}$. For warming up the heating medium to $55^{\circ} \mathrm{C}$, an electric heater/boiler will be used [42,43].

\subsubsection{High-Temperature Water-to-Water Heat Pump}

This heat pump can operate using the heat contained in the return water in the district heating network. It can be used in places where the demand for supplied heat has increased and it is not possible to expand the network infrastructure. The use of a heat pump will allow for greater use of the available heat of the return water in the heating network or waste heat, where available. The heat pump can supply heat up to $80^{\circ} \mathrm{C}$. However, the lower the temperature, the higher the efficiency of the device. This type of heat pump can be used in both new and existing buildings, adapted to high supply temperatures.

\subsubsection{Two-Stage Heat Pump System}

This kind of heating system can be used in installations where a high-temperature parameter is needed. The first stage of the system consists of brine-to-water or air-to-water heat pumps, while the second stage is a high-temperature heat pump. Both heat pumps are connected to each other by a water line, where, in order to achieve the highest possible SPF factors, it is possible to bypass the second stage, for example, if the supply temperature depends on the outside temperature and only the first stage may be necessary on warmer days. Such a combination of heat pumps also allows the system to work for cooling.

The main characteristic feature of the proposed technological solution is the modularity of the installation with a heat pump. Having only three devices, but as part of a modular system (a brine-to-water heat pump, an air-to-water heat pump, and a high-temperature heat pump), it is possible to handle seven cases of operation:

1. Brine-to-water heat pump (Module A);

2. Air-to-water heat pump (Module B);

3. Heat pump for heat withdrawal from the district heating return (Module C);

4. High-temperature two-stage heat pump (brine-to-water first stage) (Modules $\mathrm{A}+\mathrm{C}$ ); 
5. Two-stage high-temperature heat pump (first stage air-to-water type) (Modules B $+\mathrm{C}$ );

6. Hybrid heat pumps-brine-to-water heat pumps and air-to-water heat pumps connected in one installation (Modules A + B);

7. Hybrid heat pumps with a high-temperature module-brine-to-water heat pumps and air-to-water heat pumps fastened together in one installation-and a second stage heat pump (Modules $A+B+C$ ). Installation dedicated to buildings requiring high supply temperature and, at the same time, having insufficient space for installation in the first stage of ground source heat pumps.

Moreover, in most of the above cases, it is possible to provide both heating and cooling.

\subsection{Modular Heat Pump Uses}

1. Heat production: low temperature $\left(35^{\circ} \mathrm{C}\right)$; medium temperature $\left(55^{\circ} \mathrm{C}\right)$; high temperature $\left(70^{\circ} \mathrm{C}\right)$;

2. Production of heat (with different parameters) and cold;

3. Adapting the heating device to a given facility-possibility of using a geothermal source, outdoor air, waste heat, and heat from the return pipeline as heat sources;

4. Construction of a heat source with a capacity of up to $500 \mathrm{~kW}$ from manufactured modules.

\subsection{Use of Photovoltaic Panels}

The power grid must be prepared for the uncontrolled reception of electricity generated when there is no corresponding demand. Therefore, it is valuable to increase self-consumption (the use of electricity generated locally and at the time it is produced).

Photovoltaics, as an environmentally friendly, renewable energy source, should be considered in this regard. At the same time, it is a favorable circumstance that many consumers of electricity are constantly operating. Adequate adjustment of the total power of many photovoltaic installations to the total power of all electrical devices and machines (circulation pumps, metering devices, as well as office and workshop equipment) may allow for a significant increase in self-consumption than when considering individual receivers separately.

Domestic hot water preparation can be correlated with sun exposure, and the heat pump can use the electricity supplied by the PV plant to heat rooms in transitional periods. Heat pump and inverter communication is necessary. If the heat pump would also be used for cooling, the photovoltaic system can be dimensioned to match the electricity demand generated in summer. Due to the close correlation between the cooling demand and sunlight, solar farms work well with air conditioners and other cooling devices.

In the case of balancing production and demand, a photovoltaic installation can be an effective and sufficient source of electricity that will cover the annual electricity demand generated by the heat pump installation, both when it is used for heating and cooling. In both, it is necessary to operate in cooperation with an external, controllable source of electricity. It can be a public electricity grid, in which the distribution network operator (DSO) is responsible for controlling and ensuring the availability of an appropriate amount of electricity, or cooperation within a cluster or an energy cooperative in which its operator is responsible for the control.

The optimal choice of the location of the photovoltaic installation cooperating with the heat pumps should take the following into account:

- $\quad$ Possibility to install PV modules near the receiver;

- Profile of the demand for electricity generated by the heat pump-not only the annual distribution of electricity demand is important but also the planned energy consumption during the day;

- Possibility of using heat/cold stores;

- Method of accounting for excess production. 


\subsection{Prospective Areas}

In the area of the planned activity, namely Krakow Nowa Huta Przyszłości, access to geothermal water resources with the following parameters of a single intake can be expected:

- Heating power of approximately 1.5 MW at the Upper Jurassic horizon (ca. $700 \mathrm{~m}$ below ground level). Expected temperature at the head of $24{ }^{\circ} \mathrm{C}$ with a capacity of ca. $70 \mathrm{~m}^{3} / \mathrm{h}$ (Table 1). Due to low temperatures, it should be assumed that heat pumps are used. The expected investment assuming single-hole operation and the discharge of water after cooling to surface watercourses seems possible due to their low mineralization;

- Heat capacity of approximately 2.8 MW when exploiting the Devonian horizon (1.8 km below ground). The expected temperature at the head of $50{ }^{\circ} \mathrm{C}$ with a capacity of $55 \mathrm{~m}^{3} / \mathrm{h}$ - such parameters allow the direct use of geothermal energy provided that low-temperature heating systems (e.g., large surface heating area or radiator heating) are used. A high expected level of expenditure is primarily related to the need to make a doublet of wells because the cooled water will have high mineralization (approximately $100 \mathrm{~g} / \mathrm{L}$ ), which does not allow it to be discharged into surface watercourses.

The use of geothermal energy may be advisable in the case of the Recreation and Recreation Center. This facility will also be able to use the balneotherapeutic qualities of geothermal waters. This is a very significant added value of such a solution. The power of the geothermal intake $(2.8 \mathrm{MW})$ is slightly lower than the recipients' demand for power $(2.9 \mathrm{MW})$. At the same time, with a fairly high temperature of the head, it can be presumed that a significant part of the basic energy demand of the facility can be covered with geothermal energy. The possibility of using low-temperature heating installations in such facilities will be conducive to the significant use of geothermal energy.

Objects located in a planned industrial zone are characterized by large development areas and thus large roof areas. Installing photovoltaic panels on roofs could provide significant amounts of electricity. The available roof area of large-scale facilities can be estimated at approximately $360,000 \mathrm{~m}^{2}$. Assuming that $20 \%$ of this area will be set aside for the installation of photovoltaic panels, we can obtain absorber areas of 72,000 $\mathrm{m}^{2}$.

The zone of objects related to the logistic infrastructure can be heated with heat pumps using various bottom sources (brine-water pumps, air-water pumps). Using the differential settlement of electricity purchase and sale (a method similar to that used in prosumer settlements), the amount of electricity that can be generated in PV panels correlates well with the demand for heat in this zone. This is confirmed by the following estimates: assumption of the average annual COP of heat pumps and assumption of the use of air as the lower heat source. The average air temperature in Krakow for the heating season (15 September to 15 April), based on typical meteorological years and statistical climate data for the energy calculations of buildings for the Krakow-Balice station, is $3.04{ }^{\circ} \mathrm{C}$. The heating system supply temperature was set at $40^{\circ} \mathrm{C}$. The COP is 3.5. Obtaining the average annual COP value at the level of 3.5 seems realistic, considering that storage facilities do not require a high internal temperature and values of $10-16{ }^{\circ} \mathrm{C}$ seem to be sufficient for that application.

Office and laboratory facilities mostly require both heating and cooling. They are characterized by a significant demand for power and thermal energy (24.2 MW and $191 \mathrm{TJ} /$ year). The demand for heat and cooling energy suggests the advisability of using heat pumpsthey can be used for both heating and cooling purposes. The source of energy for heat pump installations in this case could be geothermal water, vertical borehole heat exchangers, and possibly atmospheric air. Electricity could come, to a certain extent, from the installation of photovoltaic cells. However, the absorber surface will be much smaller here than in the previous zone. The generated electricity will balance the current needs of office buildings rather than the energy consumption of heat pumps.

Due to the instability of the operation of renewable energy installations and different seasonal demands for cooling and heating, the use of seasonal heat storage should be considered. Considering the significant demand for power, the use of aquifer thermal 
energy storage (ATES) technology seems interesting here. The use of borehole thermal energy storage (BTES) is of course also possible; although it will be dedicated to individual facilities. It may also be advisable to use solar collectors, but to a limited extent, because office and laboratory facilities are not consumers of domestic hot water in large quantities. The consumption is rather minor. Solar collectors can, however, be used in conjunction with energy storage systems and can be used for water pre-heating in the recreation center.

In all of the analyzed facilities, taking into account the development of technology in the field to cover energy needs, it is worth considering the use of the smart grid system idea at the stage of preparing technical projects. This consists of connecting consumers with different time needs for heating and cooling. Smart grids are usually associated with solutions for the production and consumption of electricity, but their idea can be easily transferred to the production and consumption of heat energy. This idea favors the increased acquisition of renewable and waste energy.

\section{Conclusions}

This study consisted of the concept of upgrading the district heating system by means of the integration of hybrid modular heat pumps, deep geothermal waters, and PVs in Krakow, Poland.

Both the location of Krakow and its geological conditions cause numerous limitations in improving the heating sector. The city's geothermal potential is estimated to be moderate. This is due to the low temperature of the geothermal waters occurring here, which is caused by the geology of these areas. It is assumed that the Devonian and the Upper Jurassic aquifers will provide geothermal waters with temperatures of 50 and $24^{\circ} \mathrm{C}$, respectively. In the south of the city, sulfide healing waters have been found, which constitute valuable deposits with balneotherapeutic potential. However, they are a source of limitation for the energy sector in relation to waters protection and the mining areas delineated in their areas of occurrence. As a result, there is no possibility of installing geothermal installations or ground heat pumps with longer vertical exchangers.

The use of innovative modular heat pumps will allow for a better adjustment of the system to the recipient who, with a traditional system, could not count on a heating network.

Considering PV market deployment, the research conducted so far shows certain limitations, which result both from the meteorological conditions and from the geographical location of the city. A clear obstacle for the application of installations is dense urban development and the quantity of such installations. To avoid thermal pollution and a mutual environmental impact, data about ground- and water-sourced installations should be collected - a task that has not yet been carried out.

The development of geothermal and PV solutions in Krakow will help to promote a low-carbon energy transition to achieve the goal of a sustainable and resilient city concept. Thus, more of the city inhabitants will be able to benefit from renewable energy, and renewable energy resources will be used more intensively.

Author Contributions: Conceptualization, E.H.; methodology, E.H. and M.H.; validation, J.K. and W.L.; resources, G.P. and W.L.; writing-original draft preparation, E.H.; writing-review and editing, M.H. and G.P.; visualization, E.H. and M.H.; supervision, P.J. All authors have read and agreed to the published version of the manuscript.

Funding: This research was funded by MPEC S.A.-Krakow District Heating Company and the statutory research program at the Faculty of Geology, Geophysics and Environmental Protection, AGH University of Science and Technology in Krakow, Poland, Statutory Work No. 16.16.140.315/05.

Institutional Review Board Statement: Not applicable

Informed Consent Statement: Not applicable

Conflicts of Interest: The authors declare no conflict of interest. 


\section{References}

1. Eames, M.; Dixon, T.; Lannon, S.C.; Hunt, M.; De Laurentis, C.; Marvin, S.; Hodson, M.; Guthrie, P.; Georgiadou, M.C. Retrofit 2050: Critical Challenges for Urban Transitions; Cardiff University: Cardiff, UK, 2014.

2. Haarstad, H.; Wathne, M.W. Are smart city projects catalyzing urban energy sustainability? Energy Policy 2019, 129, 918-925. [CrossRef]

3. Mendizabal, M.; Heidrich, O.; Feliu, E.; García-Blanco, G.; Mendizabal, A. Stimulating urban transition and transformation to achieve sustainable and resilient cities. Renew. Sustain. Energy Rev. 2018, 94, 410-418. [CrossRef]

4. Kljajić, M.V.; Anđelković, A.S.; Hasik, V.; Munćan, V.M.; Bilec, M. Shallow geothermal energy integration in district heating system: An example from Serbia. Renew. Energy 2020, 147, 2791-2800. [CrossRef]

5. Soltani, M.; Kashkooli, F.M.; Dehghani-Sanij, A.; Kazemi, A.; Bordbar, N.; Farshchi, M.; Elmi, M.; Gharali, K.; Dusseault, M.B. A comprehensive study of geothermal heating and cooling systems. Sustain. Cities Soc. 2019, 44, 793-818. [CrossRef]

6. Europe Population. Available online: https://www.populationof.net/europe/ (accessed on 18 February 2021).

7. Berent-Kowalska, G.; Kozieł, A.; Matysiak, J.; Dąbrowska-Ładno, J.; Dziedzina, K.; Jurgaś, A.; Peryt, S.; Roman, W.; Ciszewska, A.; Kossak, E.; et al. Energy Consumption in Households in 2018. Warszawa, 2019. Available online: https://stat.gov.pl/obszarytematyczne/srodowisko-energia/energia/zuzycie-energii-w-gospodarstwach-domowych-w-2018-roku,2,4.html (accessed on 17 February 2020).

8. Sayegh, M.; Danielewicz, J.; Nannou, T.; Miniewicz, M.; Jadwiszczak, P.; Piekarska, K.; Jouhara, H. Trends of European research and development in district heating technologies. Renew. Sustain. Energy Rev. 2017, 68, 1183-1192. [CrossRef]

9. Lund, H.; Werner, S.; Wiltshire, R.; Svendsen, S.; Thorsen, J.E.; Hvelplund, F.; Mathiesen, B.V. 4th Generation District Heating (4GDH). Energy 2014, 68, 1-11. [CrossRef]

10. Yang, J.; Zhang, Y.; Wang, R.; Shen, X.; Yu, Y.; Yi, G. Design and Operation of District Heating and Cooling System in Shanghai International Shipping Service Center. In Handbook of Energy Systems in Green Buildings; Wang, R., Zhai, X., Eds.; Springer: Berlin/Heidelberg, Germany, 2018.

11. Dimitriu, S.; Bianchi, A.-M.; Băltăreţu, F. The up-to-date heat pump-combined heat and power solution for the complete utilization of the low enthalpy geothermal water potential. Int. J. Energy Environ. Eng. 2014, 8, 189-196. [CrossRef]

12. Lauka, D.; Gusca, J.; Blumberga, D. Heat Pumps Integration Trends in District Heating Networks of the Baltic States. Procedia Comput. Sci. 2015, 52, 835-842. [CrossRef]

13. Zarrella, A.; Zecchin, R.; Pasquier, P.; Guzzon, D.; Prataviera, E.; Vivian, J.; De Carli, M.; Emmi, G. Analysis of Retrofit Solutions of a Ground Source Heat Pump System: An Italian Case Study. Energies 2020, 13, 5680. [CrossRef]

14. Gheysari, A.F.; Holländer, H.M.; Maghoul, P.; Shalaby, A. Sustainability, climate resiliency, and mitigation capacity of geothermal heat pump systems in cold regions. Geothermics 2021, 91, 101979. [CrossRef]

15. Perego, R.; Viesi, D.; Pera, S.; Santa, G.D.; Cultrera, M.; Visintainer, P.; Galgaro, A. Revision of hydrothermal constraints for the installation of closed-loop shallow geothermal systems through underground investigation, monitoring and modeling. Renew. Energy 2020, 153, 1378-1395. [CrossRef]

16. Gunawardhana, L.N.; Kazama, S.; Al-Rawas, G.A. Simulating thermal pollution caused by a hypothetical groundwater heat pump system under different climate, operation and hydrogeological conditions. Geotherm. Energy 2015, 3, 19. [CrossRef]

17. Ferguson, G.; Woodbury, A.D. Observed thermal pollution and post-development simulations of low-temperature geothermal systems in Winnipeg, Canada. Hydrogeol. J. 2006, 14, 1206-1215. [CrossRef]

18. Pophillat, W.; Attard, G.; Bayer, P.; Hecht-Méndez, J.; Blum, P. Analytical solutions for predicting thermal plumes of groundwater heat pump systems. Renew. Energy 2020, 147, 2696-2707. [CrossRef]

19. Maya, S.M.; García-Gil, A.; Schneider, E.G.; Moreno, M.M.; Epting, J.; Vázquez-Suñé, E.; Marazuela, M.Á.; Sánchez-Navarro, J.Á. An upscaling procedure for the optimal implementation of open-loop geothermal energy systems into hydrogeological models. J. Hydrol. 2018, 563, 155-166. [CrossRef]

20. Kraków NHP. Available online: https:// knhp.com.pl/ (accessed on 1 February 2021).

21. Łazęcki, A.; Soluch, M.; Mleczek, M.; Tyczka, G. Heat Map for Krakow; MPEC: Krakow, Poland, 2020.

22. Hajto, M.; Krakowie, A.A.G.-H.I.S.S.W. Potencjał geotermalny Polski oraz możliwości adaptacji międzynarodowej klasyfikacji zasobów geotermalnych UNFC-2009. Nafta-Gaz 2018, 74, 898-904. [CrossRef]

23. Hajto, M.; Kotyza, J.; Plata, J.; Pasek, P.; Ciapała, B. Project of Geological Works for the Exploration Borehole for Thermal Waters-Kraków GT-1 in Kraków; Centre of Sustainable Development and Energy Conservation of the AGH University of Science and Technology in Krakow; IZE: Krakow, Poland, 2020; p. 79.

24. Górecki, W. (Ed.) Atlas of Geothermal Waters and Energy Resources in the Western Carpathians; AGH-UST: Kraków, Poland, 2006. Available online: https:/ / scholar.google.com/scholar_lookup?title=Atlas+of+Geothermal+Waters+and+Energy+Resources+ in+the+Western+Carpathians\&author=G\%C3\%B3recki,+W.\&publication_year=2006 (accessed on 1 February 2021).

25. Barbacki, A. Paleozoic Reservoirs at the Basement of the Cracow-Kielce Region (Southern Poland): Possibilities of Utilising Geothermal Energy. Prz. Geol. 2004, 52, 243-252. Available online: https://www.pgi.gov.pl/images/stories/przeglad/pdf/pg_ 2004_03_08a.pdf (accessed on 18 February 2021).

26. Kulma, R. Basics of Calculating Groundwater Filtration; Wyd. AGH: Kraków, Poland, 1995.

27. Haładus, A.; Kulma, R. Groundwater Dynamics: Examples of Calculations. Th. 2. Inflows to Water Intakes; Wyd. AGH: Kraków, Poland, 2014. (In Polish) 
28. Łazęcki, A. Assumptions for the Plan of Supplying the Municipality of Krakow with Heat, Electricity and Gas Fuels; MPEC SA: Krakow, Poland, 2013. (In Polish)

29. URE. Heat Energy in Numbers; Urząd Regulacji Energetyki (The Energy regulatory office); URE: Warszawa, Poland, 2018. (In Polish)

30. MPEC SA. Development Plan of MPEC S.A. in Krakow in the Scope of Meeting the Current and Future Demand for Heat. Long-term Material and Financial Plan of the Company for 2020-2025 (2020); MPEC SA: Kraków, Poland, 2020; p. 79. (In Polish)

31. Bielewicz, A.; Dziamara-Rzucidło, K.; Guła, A.; Koc, D.; Kojs, M.; Panek, A.; Rajkiewicz, A.; Sokulska, A.; Staniaszek, D.; Walencka, M.; et al. Building Retrofit Strategy: Roadmap 2050; European Climate Foundation: Kraków, Poland, 2014 ; p. 112.

32. Nowak, T. Large Scale Heat Pumps in Europe. Industrial \& Commercial Heat Pump Working Group; European Heat Pump Association: Brussels, Belgium, 2017.

33. Kiss, P. Efficient solution for large heat pumps: Wastewater heat recovery. In Proceedings of the 12th IEA Heat Pump Conference 2017, Rotterdam, The Netherlands, 15-18 May 2017; p. 11.

34. PORT PC, Heat Pumps in the John Paul Ii Center in Krakow. Information Campaign "Heat Pumps-Savings in Practice". Polish Organization for the Development of Heat Pump Technology (PORT PC). 2016. Available online: http://portpc.pl/pompyciepla-krakowskim-centrum-jana-pawla-ii/ (accessed on 1 February 2021).

35. Geoplasma CE. Available online: https://portal.geoplasma-ce.eu/webgis/krakow (accessed on 18 February 2021).

36. Hajto, M.; Przelaskowska, A.; Machowski, G.; Drabik, K.; Ząbek, G. Indirect Methods for Validating Shallow Geothermal Potential Using Advanced Laboratory Measurements from a Regional to Local Scale-A Case Study from Poland. Energies 2020, 13, 5515. [CrossRef]

37. Ozimek, J.; Koczorowski, J. Expertise on the Technical and Operational Data of Shallow Geothermal Installations, including Geothermal Heat Pumps: Ground Heat Exchangers and Water-Water Installations, Along with the Analysis of the Possibility of Specialist TRT Measurements in the Pilot Area of Krakow; GeoPLASMA-CE. Project Deliverable D.T4.2.3; Interreg CENTRAL EUROPE Programme Joint Secretariat Kir: Wrocław, Poland, 2018; p. 15. (In Polish)

38. Lachman, P. Raport Rynkowy PORT PC; Heat Pump Market in Poland in 2010-2018. Development Perspectives for the Heat Pump Market until 2030; PORT PC: Kraków, Poland, 2019; p. 46. (In Polish)

39. Hajto, M.; Ciapała, B.; Zabek, G.; Michna, M.; Papiernik, B. (Eds.) Reviewed Strategies for the Use of Shallow Geothermal Energy in the Investigated Pilot Areas-Kraków; GeoPLASMA-CE Project Deliverable D.T4.2.3; Interreg CENTRAL EUROPE Programme Joint Secretariat Kir: Kraków, Poland, 2019; p. 70.

40. Górecki, W.; Kotyza, J.; Hałaj, E.; Luboń, W.; Pełka, G.; Sowiżdżał, A.; Dawiec, D.; Smaczna, P.; Malik, D. Education and research in the field of renewable sources of energy in the Centre of Sustainable Development and Energy Savings WGGIOS AGH in Miekinia. In Proceedings of the International Conference-Renewable Energy Sources (ICoRES 2019), Krynica, Poland, 9-11 June 2020; Volume 154, p. 07006. [CrossRef]

41. Air-to-water heat pum-Maxima. Galmet sp. Z o. o. In Installation and Maintenance Manual. Głubczyce, Poland, 2017. (In Polish). Available online: https://galmet.com.pl/uploads/productfiles/instrukcja-instalacji-i-konserwacji-maxima-20-42gt07062019.pdf (accessed on 1 February 2021).

42. Operating and Assembly Manual. Galmet sp. Z o. o., Głubczyce, Poland; 1.1 edition. 2017. (In Polish). Available online: https:/ / galmet.com.pl/uploads/productfiles/instrukcja-obslugi-i-montazu-sterownika-powietrznej-pompy-ciepla-airmaxgalmet-ecotronic200-g_dtr_pl_wydanie_11.pdf (accessed on 1 February 2021).

43. Pełka, G.; Luboń, W.; Malik, D.; Kołton, K.; Kołton, W. An Innovative Air-Water Heat Pump with Ecological Refrigerant. Renew. Energy Sources Eng. Technol. Innov. 2018, 519-528. [CrossRef] 